Г. А. Новичкова. - М. : ИФ РАН, 2001. - 142 с. - Режим доступа: http://pedlib.ru/Books/5/0261/5_0261-1.shtml. 9. Павлова Т. С. Співвідношення моралі i права у філософії І. Канта (історикофілософський аналіз) : автореф. дис. на здобуття наук. ступеня канд. філософ. наук: спец. 09.00 .05 «Історія філософії» / Т. С. Павлова. - Дніпропетровськ, 2007. - 18 с. 10. Смігунова О. Г. Естетика I. Канта: продуктивна уява і принцип доцільності : автореф. дис. на здобуття наук. ступеня канд. філософ. наук: спец. 09.00.08 «Естетика» / О. Г. Смігунова. - К., 2007. - 18 с.

\title{
ЄВРОПЕЙСЬКІ ТЕНДЕНЦЇ̈ В РОЗВИТКУ ОСВІТИ ДОРОСЛИХ
}

\footnotetext{
У статті охарактеризовано міжнародні тендениії розвитку освіти дорослих на категоріальному, практичному, історико-педагогічному рівнях. Розкрито роль освіти дорослих у забезпеченні позитивних змін суспільного життя; наголошено на важливості проведення порівняльних досліджень у галузі освіти дорослих.

Ключові слова: порівняльні дослідження у сфері освіти дорослих, зміст освіти дорослих, специфіка освіти дорослих.
}

В статье охарактеризованы международные тенденции развития образования взрослых на категориальном, практическом, историко-педагогическом уровне. Раскрыта роль образования взросльх в обеспечении позитивных изменений общественной жизни; подчеркивается важность проведения сравнительных исследований в области образования взрослых.

Ключевые слова: сравнительные исследования в сфере образования взросльх, содержание образования взросльх, специфика образования взрослых.

The article describes some international trends at adult education development on the level of category, practice, history and comparative-education. The role of adult education in development of positive trends in social life is highlighted at the article either, main attention here is attracted to the importance of comparative research in the field of adult education.

Key words: comparative investigations in the adult education area, content of adult education, specific of the adult education.

Протягом останніх років спостерігається кількісне зростання контингенту тих, хто навчається у системах післядипломної освіти, підвищення кваліфікації, перекваліфікації. Саме тому виникає необхідність дослідження проблематики освіти дорослих, яка безпосередньо пов'язана із цією сферою.

Початок XXI століття характеризується перетворенням освіти дорослих у потужний чинник суспільного прогресу $\mathrm{i}$ 
розвитку особистості. Концептуальний аналіз цієї галузі потребує розвитку методологічних основ дослідження, осмислення цієї проблематики в контексті історичних і сучасних тенденцій розвитку неперервної освіти. Серед актуальних завдань - проблема комплексного дослідження процесу формування і розвитку концептуальних основ, історичних передумов, порівняльного дослідження освіти дорослих, розроблення наукових рекомендацій 3 питань модернізації національних систем освіти дорослих, дослідження тенденцій модернізації освіти дорослих як феномену неперервної освіти. Водночас варто враховувати недостатню розробленість теоретико-методологічних основ порівняльних досліджень у сфері освіти дорослих і необхідність узагальнення теоретичних засад окресленої наукової проблеми.

Важливо всебічно охарактеризувати процес становлення і розвитку теорії та практики освіти дорослих, проаналізувати особливості формування андрагогічних основ дослідження навчання дорослих, конкретизувати сутнісні характеристики розвитку освіти у ХХ ст. («освіти дорослих протягом життя», «неперервної освіти дорослих», «теорії і методики освіти дорослих», «подальшої освіти дорослих», «відновлювальної освіти дорослих», «неформальної освіти дорослих»), розкрити різноманітні психолого-педагогічні підходи до модернізації освіти дорослих (мотиваційно-програмно-цільовий підхід, діяльнісний підхід, аксіологічний підхід, особистісно зорієнтований підхід тощо), систематизувати провідні тенденції розвитку освіти дорослих (модернізація західних парадигм освіти дорослих, демократизація суспільства засобами освіти дорослих, розвиток соціального партнерства тощо). Отже, необхідний системний підхід до аналізу теоретикометодологічних основ освіти дорослих і тільки на цих засадах - розроблення пропозицій щодо подальших порівняльних досліджень в окресленій сфері.

Mета статті полягає в характеристиці міжнародних тенденцій розвитку освіти дорослих та конкретизації європейських тенденцій розвитку цієї сфери на історико- та порівняльно-педагогічному рівнях.

Сучасні глобальні тенденції розвитку освіти дорослих посилюють інтерес науковців до національної специфіки розвитку галузі. Національна своєрідність еволюції цієї сфери притаманна більшості європейських країн. Про це свідчить 
відсутність стереотипних підходів та стандартів визначення стратегії розвитку освіти дорослих.

Зазначаємо, що концепція освіти дорослих («adult education») сформувалася як самостійний науковий напрям у 70-х роках XX ст. Це одна 3 найбільш дискусійних сфер, що пояснюється специфікою загальнокультурного й освітнього рівня розвитку різних країн та неоднозначністю трактування категорії дорослої людини (Р. Каффарелла, А. Грейс, П. Джарвіс, М. Ноулз, А. Роджерс та ін.).

Найпоширенішим тлумаченням поняття «освіта дорослих» є розгляд іï як будь-якої освітньої діяльності дорослої людини незалежно від змісту, професійної спрямованості, термінів і форм навчання, ступеня інституціалізації. Єдиним критерієм є вік людини [2].

Останнім часом простежується тенденція до звуження значення цього поняття: воно трактується як «інституціоналізовані послуги 3 освіти дорослих» після отримання основної освіти. Таке визначення розглядуваного навчання зближує його з сучасними визначеннями зарубіжними авторами понять «продовжена освіта» та «додаткова освіта» [4]. Наявна також тенденція до злиття різних термінів, що відображає зближення концептуальних підходів до їх трактування. Прикладом цього $є$ поєднання термінів «продовжена освіта» та «освіта дорослих» у поняття «продовжена освіта дорослих» («adult continuing education»), що відповідає понятійному апарату терміна «додаткова освіта дорослих». У такому ж значенні використовуються в наукових працях терміни «освіта дорослих» («adult education») і «продовжена освіта» («continuing education») [5].

Натепер концепція неперервної освіти, на відміну від традиційної освітньої парадигми, не визнає остаточної завершеності в розвитку особистості; це стосується як професійного, так й особистісного потенціалу людини. Актуального значення набуває проблематика порівняльного аналізу процесу розвитку неперервної освіти взагалі та освіти дорослих зокрема. Реалізація цього завдання потребує чіткого визначення такого: теоретико-методологічних засад дослідження тенденцій розвитку освіти дорослих у країнах Західної та Східної Європи, концептуальних підходів до аналізу розвитку національних систем зазначених держав, нормативного забезпечення ефективного розвитку освітніх систем у країнах Західної та Східної Свропи у другій половини ХХ століття. 
Однією $з$ найбільш актуальних проблем освіти дорослих в Україні є проблема формування професійної культури майбутніх фахівців, їхньої конкурентоспроможності, адаптації до сучасних умов та вимог ринку праці.

Серед причин відставання освіти дорослих в Україні від практики технологічно розвинених країн можна визначити такі:

- оцінювання потенційних можливостей освіти дорослих;

- недостатності наукового обгрунтування освітньої політики загалом;

- зосередження уваги на проблемах освіти юного покоління;

- відсутності необхідної нормативно-правової бази;

- недостатнього дослідження зарубіжного досвіду в цій сфері;

- замалої кількості рекомендаційних документів міжнародних організацій.

Саме тому важливо досліджувати історичні та порівняльно-педагогічні аспекти розвитку освіти дорослих, а також виявляти зв'язок із сучасністю.

1986 року відбулася перша міжнародна конференція 3 питань історії освіти дорослих в Оксфордському університеті. У 1989 році в Університеті Сіракузи (США) канадськими та американськими науковцями здійснено проект, спрямований на аналіз взаємовідношень між професійною освітою та освітою дорослих [7].

Історичний аналіз свідчить, що в 1919 році було засновано Світову асоціацію з питань освіти дорослих у Лондоні. Починаючи з 1949 року ЮНЕСКО постійно актуалізує проблематику розвитку міжнародного руху у сфері освіти дорослих. В Ельсінорі (Данія, 1949 рік), у Монреалі (Канада, 1960 рік), у Токіо (Японія, 1972 рік), у Парижі (Франція, 1985 рік) та Гамбурзі (Німеччина, 1997 рік) було проведено міжнародні симпозіуми 3 питань освіти дорослих. На VI Міжнародній конференції у Бразилії, що відбулася в грудні 2009 року, експерти ЮНЕСКО затвердили постанову про збільшення фінансування і підвищення відповідальності урядів країн за освіту дорослих.

Зрозуміти важливість порівняльних досліджень у сфері освіти дорослих, їх актуальне значення у світовому педагогічному контексті допоможе розгляд історичних передумов діяльності Міжнародного товариства у сфері порівняльних 
досліджень у галузі освіти дорослих (ISCAE). У працях про стратегію розвитку, історичні чинники та перспективи діяльності ISCAE iï президент Джост Ройшман зазначає, що товариство пройшло низку історичних етапів, які забезпечили його сучасну якість.

Міжнародна проблематика у сфері освіти дорослих, на думку М. Боукувалас, - це ідея, яка сягає корінням в античність, оскільки ще Олімпійські ігри створювали основу для міжнародного порозуміння, коли спортсмени і митці збиралися не лише для конкуренції, але й для демонстрування взаєморозуміння лідерів різних міст. Їхній досвід засвідчує миротворчу філософію освіти дорослих різних країн світу, їі гуманізм та орієнтацію на загальнолюдські цінності; такі принципи - і в основі міжнародної громадської діяльності ISCAE.

За час свого існування ISCAE намагається розвивати i підтримувати міжнародні стандарти у сфері методології міжнародного порівняння освіти дорослих, що може допомогти дослідникам цього напряму. Серед перешкод на цьому шляху можна визначити міжнародну комунікацію (англійську мову), якою не володіють усі європейські науковці, хоча вона вже давно $є$ мовою міжнародного наукового спілкування.

Серед провідних гуманістичних тенденцій розвитку освіти дорослих визначаємо формування національних систем освіти дорослих у провідних європейських країнах, іiі реформування і модернізацію у другій половині XX століття, розвиток методологічних основ неперервної освіти у країнах ЄC на сучасному етапі та в процесі їх історичного становлення. Однак потребують узгодження різноманітні трактування понять методології порівняльних досліджень у сфері освіти дорослих, зокрема - категорії, закони, функції, філософія, міждисциплінарний підхід, методологія андрагогіки, наукового пізнання, наукового дослідження, розвитку мислення дорослої людини.

Отже, увагу як вітчизняних, так і зарубіжних науковців привертає проблема розвитку національних демократичних традицій у сфері освіти дорослих. У контексті цієї проблематики важливо визначити методологічні засади системного підходу до аналізу тенденцій національного розвитку освіти дорослих, методологічні основи системного підходу до порівняльного вивчення світових тенденцій, а також розвит- 
ку неперервної освіти у глобальному вимірі, концептуальні характеристики еволюції системи освіти дорослих у другій половині XX століття.

Сучасний етап світового розвитку освіти характеризується зростанням ролі навчання дорослих у забезпеченні позитивних змін різних сторін життя суспільства. У такому навчанні важливо зважати на особливості дорослої людини, зокрема, iii життєвий досвід як важливий компонент змісту навчання. Британські дослідники визначають різні особливості дорослих, які необхідно враховувати в навчанні, головними 3 яких $€$ такі:

- наявність у дорослих власної мотивації до навчання;

- детермінованість процесу навчання професійними, соціальними, побутовими і тимчасовими чинниками;

- наявність певних навчальних стереотипів унаслідок попереднього навчального досвіду, які можуть сприяти чи заважати новому навчанню.

Освіта дорослих відрізняється від освіти юного покоління своїми цінностями і мотивами, метою і завданнями, змістом і формами організації, способами контролю й оцінки, а отже i своїми результатами. Для забезпечення високого рівня ефективності освіти дорослої людини важливо проаналізувати кожен із зазначених компонентів та усвідомити їх особливості. Насамперед розглянемо докладніше зміст навчання.

Зміст неперервної професійної освіти дорослих зумовлений, по-перше, потребами суспільства, по-друге, - потребами самого фахівця.

Освіта визначається як процес і результат засвоєння систематизованих знань, умінь і навичок, як необхідна умова підготовки людини до життя і праці, як система цілеспрямованого впливу на особистість із метою її адаптації до потреб суспільства. Потреби суспільства часто співвідносять із потребами держави, що призводить до ототожнення соціального замовлення з державним замовленням.

Питання змісту освіти дорослих можна розглядати в таких аспектах: 1) освіта як спосіб розв'язання життєвих проблем дорослої людини; 2) проблемність як характеристика викладання матеріалу, за якої знання передаються не у вигляді готової інформації, рецепта (дорослі самі навчаються, залучаючись до евристичного пошуку рішень; при цьому актуалізуються їхні знання, досвід, аналітичні вміння, усвідомлюється недостатність знань і тим самим стимулюється пізнавальний 
процес); 3) проблема як вихід за межі конкретної певної галузі у більш широкі сфери науки, суспільного життя, мистецтва; 4) зв'язок навчання з глобальними проблемами людини і людства.

Освіта дорослих є найбільш мобільною сферою освіти. Для забезпечення оперативності іiі змісту вона повинна бути відкритою, а іiї організація має допускати практично неперервне коригування навчальних програм, планів. При цьому необхідно враховувати як важливі запити дорослих людей, їхні потреби, актуальність наукових знань, так і зміни, які відбуваються в соціально-економічній і політичній ситуації країни [3].

Специфіка освіти дорослих полягає, насамперед, у тому, що їі контингентом є залучені у сферу зайнятості повнолітні громадяни. Це зумовлює важливий методологічний принцип, якого необхідно дотримуватися у формуванні нормативноправової бази: законодавство про освіту дорослих повинно регулювати відносини, пов'язані з професійною діяльністю, iз різними сферами життя людини, суспільства, держави.

Освіта дорослих - соціальний інститут, що історично склався. Це складна поліфункціональна, соціальнопедагогічна і соціально-культурна система, спрямована на задоволення професійно-освітніх та особистісних потреб людини. Вона включає всі види післявишівської професійної і додаткової, формальної та неформальної освіти, спрямована на збереження і розвиток загального освітнього простору. Комплекс проблем, пов'язаних із іiі функціонуванням і розвитком, має свою змістову своєрідну специфіку, зумовлену особливостями контингенту дорослих людей.

Освіта дорослих грунтується на теорії навчання дорослих - андрагогіці, науково-методичною основою якої $є$ технологія навчання дорослих. Засадничими для неї $є$ концепція вільного, «відкритого» навчання (open learning - англ.), психологія навчання дорослих, що розвивається в контексті неперервної освіти людини впродовж усього життя.

Сучасне застосування інновацій у сфері освіти дорослих можливе на основі використання дистанційної форми навчання, комунікаційно-інформаційних технологій, оскільки ця сфера не може ефективно функціонувати й розвиватися без сучасного інформаційного забезпечення (створення баз даних, використання комп'ютерних технологій та можливостей системи Інтернет). 
Для ефективності такого навчання, на думку О. Топоркової, андрагогам рекомендується дотримуватися певних правил:

1) допомагати тим, хто навчає, виявляти освітні потреби, використовувати вже набутий досвід і здобуті знання для їх подальшого використання як засобу навчання;

2) виявляти толерантність до можливих фізичних недоліків дорослих;

3) навчати слухачів ефективних технологій навчання i caмонавчання, які допоможуть сформувати їм необхідні когнітивні вміння і навички як практичного, так і теоретичного характеру;

4) використовувати методи навчання, які посилюють відчуття власної гідності і розвивають інші людські якості;

5) створювати на заняттях комфортну психологічну атмосферу, що полягає у взаємодії андрагога і дорослої людини [6].

У дискусіях з проблем освіти дорослих європейські науковці використовують різні терміни: lifelong learning (навчання впродовж життя) та lifewide learning (навчання все життя, тобто таке, що включає всі форми навчання - формальні з видачею сертифіката чи диплома, неформальні, які здійснюються на семінарах, конференціях, та інформальні, тобто самоосвіта за допомогою спілкування, використання ЗМІ, читання тощо). Серед багатьох актуальних проблем передовсім постає питання системного вдосконалення теорії $\mathrm{i}$ практики навчання дорослих у контексті системи неперервної освіти [1].

Для забезпечення мобільності змісту освіти дорослих [3] їі організаційні форми повинні передбачати механізм неперервного коригування навчальних програм, урахування потреб тих, хто навчається, сучасних наукових знань, що постійно змінюються, та змін соціально-економічної і політичної ситуації в суспільстві.

Починаючи 3 середини XX століття освіта дорослих стала одним з найважливіших засобів розвитку суспільства і людини. Доступ до освіти отримує значна кількість соціальних груп, для яких вона є одним із засобів виживання: інваліди, біженці, безробітні, пенсіонери, функціонально неграмотні працівники. У різних країнах освіті дорослих відводиться важлива роль у забезпеченні стійкого прогресу розвитку особистості та суспільства, оскільки саме вона може стати одним 
3 пріоритетних напрямів, який відкриває перспективні можливості для вирішення як наявних, так і майбутніх проблем XXI століття.

Отже, можна стверджувати, що існує необхідність розв'язання актуальних завдань, поставлених сьогоденням перед освітою дорослих, що неможливо без усвідомлення провідних тенденцій дослідження в цій сфері, адекватного й зацікавленого ставлення до цієї галузі науки громадськості, фахівців та, що важливо, представників різних державних установ і громадських організацій, рухів, налагодження між ними конструктивної співпраці. Це буде передумовою формування в суспільній свідомості відповідного ставлення до окресленої проблеми, яка нині є необхідною засадою розвитку концептуального бачення, пошуку науково обгрунтованих і практично-орієнтованих способів їі розв'язання.

Зазначені вище тенденції орієнтують на проведення порівняльних досліджень у галузі освіти дорослих, реалізацію системного підходу до концепції розвитку цієї галузі на національному рівні, формування системи соціального партнерства в контексті сучасних завдань неперервної освіти. Це сприятиме цілеспрямованому використанню наукових результатів у підготовці навчальних посібників, довідників 3 проблем освіти дорослих, виробленню рекомендацій щодо визначення конкретних способів демократизації вітчизняної системи неперервної освіти, адаптації національної освітньої системи в Україні до демократичних стандартів і концепцій європейських країн.

\section{Література}

1. Гершунский Б. С. Образование как религия третього тысячелетия: гармония знания и веры / Б. С. Гершунский. - М. : Педагогическое общество России, 2001. - 128 с. 2. Ковальчук Л. О. Система освіти зарубіжних країн : [навч. посібн.] / Л. О. Ковальчук, О. Б. Ковальчук. - Львів : Видавничий центр ЛНУ ім. Івана Франка, 2003. - 136 с. 3. Матюшкина М. Д. Основные характеристики образования взрослых / М. Д. Матюшкина // Андрагогика : [материалы к глоссарию]. - Вып.1 / науч. ред. С. Г. Вершловского и др. СПб. : СПбАППО, 2004. 4. Митина А. М. Дополнительное образование взрослых за рубежом: Концептуальное становление и развитие / А. М. Митина. - М. : Наука, 2004. - 304 с. 5. Митина А. М. Зарубежные исследования учебной мотивации взрослых / А. М. Митина // Вестник МГУ. - Сер.14. Психология. - 2004. № 2. - С. 56-65. 6. Топоркова О. В. Дополнительное образование: тенденции развития во второй половине XX века в Великобрита- 
нии / О. В. Топоркова, А. М. Митина // Новые образовательные системы и технологии обучения в вузе : [межвуз. сб. науч. тр.]. Волгоград : Политехник, 2000. - Вып. 6. - Ч. 2. - С. 15-20. 7. Breaking New Ground: The Development of Adult and Workers' Education in North America, Syracuse University, 1990. 8. Caffarella R. S. Psychosocial development of women: A critical review of the literature / R. S. Caffarella, S. K. Olson // Adult Education Quarterly.-1993. - № 43(3). - P. 125-151.

\section{ФІЛОСОФСЬКО-ЕПІСТЕМОЛОГІЧНЕ ПОНЯТТЯ НАУКОВОСТІ МЕТОДІВ ПІЗНАННЯ ТА ЇХ ПЕДАГОГІЧНЕ ВІДОБРАЖЕННЯ}

У статті розглянуто загальні підходи до методу як наукового поняття $у$ структурі пізнавального прочесу. Поява науково обтрунтованих методів пізнання (створення методології як системи принципів і способів організачії та побудови теоретичної $і$ практичної діяльності) - ие результат творчих здобутків мислителів різних часів, епох, народів. У ̈̈х доробку - визначення характеру методу, його підгрунтя та функиій.

Ключові слова: метод, методологія, навчання, пізнавальний прочес, суб'єкт пізнання, об'єкт пізнання, діалектика.

$B$ статье рассмотрены общие подходы к методу как научному понятию $в$ структуре познавательного процесса. Появление научно аргументированньх методов познания (образование методологии как системы принципов и способов организачии теоретической и практической деятельности ) - это результат творческих наработок мыслителей разных времен, эпох и народов. В их наследии - определение характера метода, его основания и функций.

Ключевье слова: метод, методология, обучение, познавательный прочесс, субъект познания, объект познания, диалектика.

The article reviews the common approaches to the method as a scientific concept in the structure of cognitive process. The emergence of scientifically based methods knowledge (a methodology as a system of principles and methods of organizing and building a theoretical and practical activities) - is the result of creative achievements of thinkers of different times, eras, nations. Their product is the nature of the method, its basis, functions.

Key words: method, methodology, instruction, cognitive process, subject of cognition, object of cognition, dialectics.

Український народ протягом століть, починаючи зі спроби встановити перші національні уряди, намагається розбудовувати українську систему освіти на найкращих світових традиціях: народності, доступності, синергетичності. Упро- 